\title{
Development phases and structural characteristics of the Penteleu- Viforâta virgin forest in the Curvature Carpathians
}

\author{
Serban Chivulescu ${ }^{(1)}$, \\ Albert Ciceu ${ }^{(1-2)}$, \\ Stefan Leca ${ }^{(1)}$, \\ Bogdan Apostol ${ }^{(1)}$, \\ Octavian Popescu ${ }^{(3-4)}$, \\ Ovidiu Badea ${ }^{(1-2)}$
}

\begin{abstract}
The stand structure of a virgin forest situated at an average altitude of $1130 \mathrm{~m}$ a.s.I. in the Milea Viforâta Nature Reserve (Southern Carpathians, Romania) was investigated to determine the specific development phases of the forest and understand how they influence the stand structure, with the aim of providing optimal solutions and structural models for sustainable forest management. All trees with breast height diameter $(\mathrm{dbh}) \geq 8 \mathrm{~cm}$ were inventoried in the study plot ( $1 \mathrm{ha})$, and the main dendrometrical variables were measured. Radial increment cores were taken from all the trees and were subsequently processed. A total of 317 trees from three species - European beech (Fagus sylvatica), silver fir (Abies alba) and Norway spruce (Picea abies) - were sampled at different development phases (optimum, ageing, breakdown and dieback, rejuvenation). Testing stand structural diversity with the Gini index, a minimal stability was found in the rejuvenation development phase and a maximum stability in the ageing phase. No significant match was found between standard theoretical functions (Normal, Weibull, Gamma and Exponential) and the observed distribution of tree diameter. Also, it was confirmed that dominance of beech in all development phases is a consequence of its high competitive ability and its capacity to endure difficult environmental and biologically stressful conditions. The results revealed a series of structural models specific to these forest ecosystems, which can help managing forests under the selection system.
\end{abstract}

Keywords: Primary Forest, Development Phases, Uneven Aged Forests, Carpathians Forest

\section{Introduction}

The Food and Agriculture Organization (UN-ECE/FAO 2000) defines virgin forests as "forests developed under natural conditions and undisturbed by human activities". In Europe, in managed forests, sus tainable management and silvicultural practices at the beginning of the $21^{\text {st }}$ century aim to reproduce virgin forest complex structures and their multi-functional outcomes (Visnjić et al. 2015). The complex ity of uneven-aged forest structures en sures economic value through superior timber quality, as well as high biodiversity at all levels (Parviainen 2005, Giurgiu 2013).
The dynamics of virgin forests, their response to stress factors, natural competition, species exclusion, species complementarity and niche development have been the subject of research and a reference model, as well as an inspiration for theories and principles of silviculture (Parviainen 2005, Vacek et al. 2014). Furthermore, due to the impact of climate change on managed forests and the new upcoming challenges, a different approach in the way forests are managed is needed. New practices and management strategies are required, and virgin forests can provide a model for future silvicultural practices (Král
(1) National Institute for Research and Development in Forestry "Marin Dracea" (Romania); (2) Transilvania University of Brasov (Romania); (3) Institute of Biology Bucharest, Romanian Academy (Romania); (4) Molecular Biology Center, Institute of Interdisciplinary Research in Bio-Nano-Sciences, Babes-Bolyai University, Cluj-Napoca (Romania)

@ Albert Ciceu (albert.ciceu@icas.ro)

Received: Mar 11, 2019 - Accepted: Jun 17, 2020

Citation: Chivulescu S, Ciceu A, Leca S, Apostol B, Popescu O, Badea O (2020). Development phases and structural characteristics of the Penteleu-Viforâta virgin forest in the Curvature Carpathians. iForest 13: 389-395. - doi: 10.3832/ifor3094-013 [online 2020-09-01]

Communicated by: Paola Mairota et al. 2018) and forest management planning to address the challenge of climate change. New approaches should include silvicultural practices aimed at improving the forest stability otherwise reached by unmanaged forests (O'Hara 2016). However, silvicultural treatments are indispensable, under certain circumstances, to achieve a higher diversity and stability then that attainable following the forest natural dynamics (Brzeziecki et al. 2018).

Virgin forests are a natural heritage of extraordinary value and timeless interest. Most of the world's remaining virgin forests survive thanks to limits on logging and restrictions to human access. However, these limitations are now being removed because of new harvesting techniques and the high value of timber, thus virgin ecosystems are becoming increasingly rare (Parviainen 2005, Giurgiu 2013). Considering the negative impacts that have been recorded on forest succession (Kral 1979), the growing research interest and concern on the survival of virgin forests are justified. used according to the reference literature (Korpel 1978, Leibundgut 1982), as synonymous of primaveral forest, primary forest and pristine forest (Schuck et al. 1994). This study focuses on understanding and modelling virgin forest development phases, defined as theoretical concepts which help
In this study, the term "virgin forest" is 
characterise the structural dynamics of natural forests (Remmert 1991) under the influence of internal and external factor (Zenner et al. 2015, Feldmann et al. 2018).

The development phases offer information on virgin forests' growth dynamics, about how natural processes run without being disturbed by human activities and also how we can reproduce these struc tures through future management prac tices (Zenner et al. 2015, Visnjić et al. 2015). The aim of this study is to determine the characteristics of each development phase in order to develop solutions for structural models applied in forest management. The main objectives of the study are: (i) to characterise the structure of a virgin stand and its development phases; (ii) to describe the stand structure in relation with diameter (for the entire stand and for each development phase) by theoretical func tions; (iii) to determine the relationships among tree species and their respective development phase, age and growth.

\section{Materials and methods}

The study area is situated in the Curvature Carpathians - more specifically, in the Penteleu Massif, which is a part of the Buzau Mountains - in a temperate continental zone at an altitude of $1128 \mathrm{~m}$ a.s.l., on a southern slope (Fig. 1). The lithological substrate is composed of sandstone and dune sand with variable granulation. The dominant winds come from NNE and the average annual temperature is $6.1^{\circ} \mathrm{C}$. The inventoried plot is part of the Milea Viforâta Nature Reserve. It is circular in shape, with a radius of $56 \mathrm{~m}$, and has an area of 1 ha. A tape was used to measure trees with a circumference $>25 \mathrm{~cm}$ at breast height, corresponding to a diameter of at least $8 \mathrm{~cm}$. The height of each tree in the plot was measured using an ultrasound instrument system (Vertex IV ${ }^{\circledR}$, Haglof, Sweden). The measured variables were: tree position, circumference, height, species, and storey position. Also, wood core samples were obtained with a Pressler's increment borer, as radial growth, together with the structure of stand in relation with tree diameter, represent the most important element in describing the stand evolution and its development phases (Hassani \& Amani 2010).

Tree radial growth was measured on cores using the software CooRecorder ${ }^{\circledast} \mathrm{v}$. 7.4 (Cybis Elektronik \& Data AB, Saltsjöbaden, Sweden) based on image analysis, and the validation of measurements was done by COFECHA software (Holmes 1983). A mean radial growth of the last ten years was computed for each tree ( $\left.i_{10}\right)$. Nonlinear regression analysis using the "nls" function in R (Baty et al. 2015) was conducted for each species to determine a radial growth (ir) model using the following mathematical expression (eqn. 1):

$$
\overline{\mathrm{ir}}_{10}=a_{0}+a_{1} d b h+a_{2} d b h^{2}
$$

where $i_{10}$ is the mean ir of the last ten years for each tree and $a_{0}, a_{1}$ and $a_{2}$ are the species-specific parameters to be estimated. The radial increment derived from wood core samples allows us to distinguish

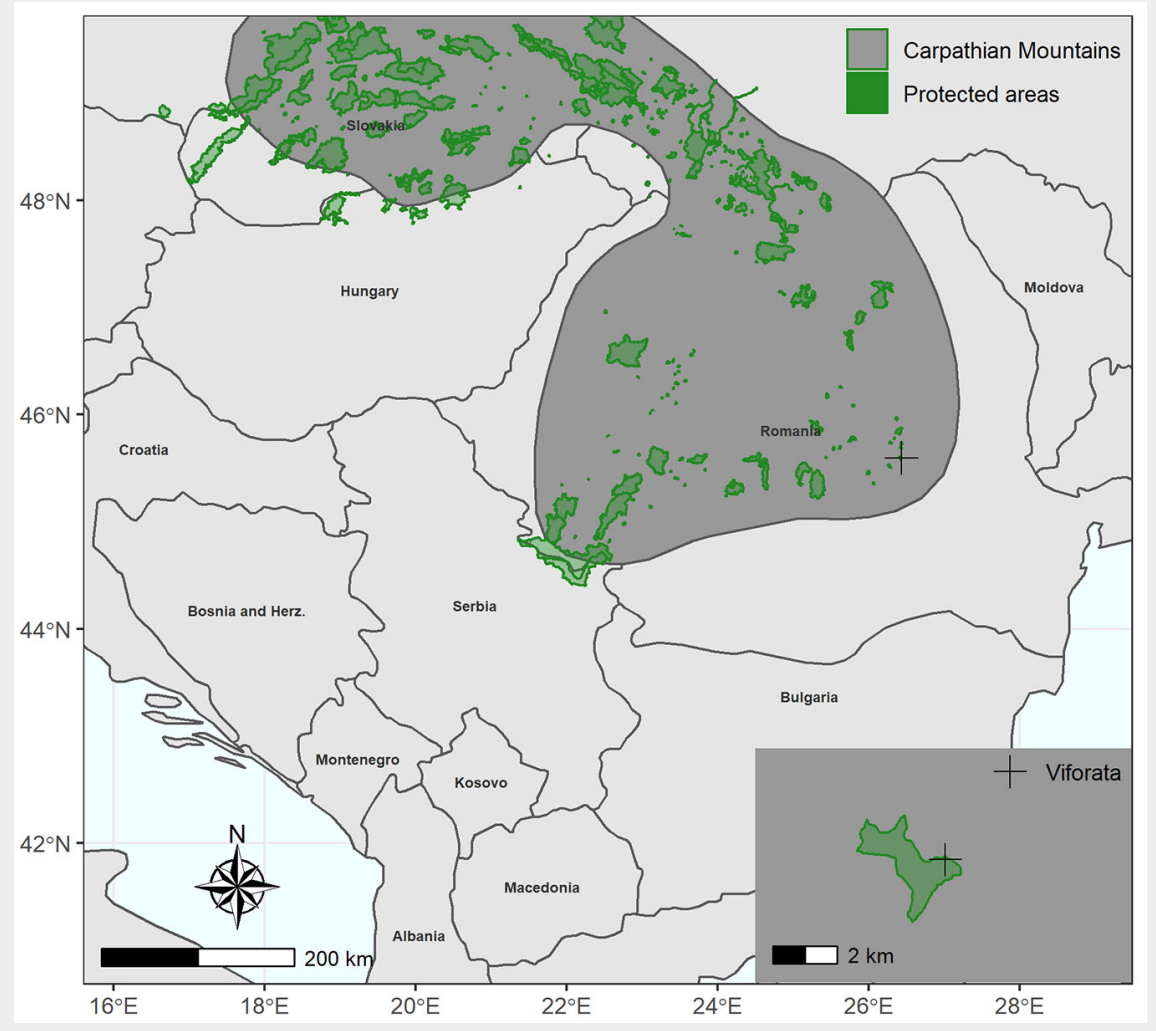

Fig. 1 - The study area (black cross) in the Milea Viforâta Nature Reserve (Romania). different growth rates among groups of trees, and thus to determine the stand's development phases.

Theoretical distributions (normal - Patel \& Read 1996; gamma - Hogg \& Craig 1978; weibull - Nawaz \& Nazrul 1980; exponential - Marshall \& Olkin 1967) were fitted using the "fitdristr" function of the $R$ "fitdistrplus" package (Delignette-muller \& Dutang 2015). Kolmogorov-Smirnov (KS - Stephens 1979), Anderson-Darling (AD -Anderson \& Darling 1954) and chi-square (CHI) tests were used to assess the fit of theoretical distribution to the experimental diameter distribution. Also, to compute the diameter limit of the stand, an exponential distribution of the following form was used (Meyer 1952 - eqn. 2):

$$
y=k \cdot e^{-\alpha x}
$$

where $y$ is the number of trees in a narrow diameter interval $y x, x$ is the diameter at breast height, $e$ is the base of the natural logarithm, and $k$ and $\alpha$ are constants characterising a certain structure.

Volume growth was established using a method based on single-inventory information and on wood cores taken from standing trees (Giurgiu et al. 2004). The following equation was used to calculate the volume of each individual tree (Giurgiu et al. 2004 - eqn. 3):

$$
\begin{aligned}
\log v & =a_{0}+a_{1} \log d b h \\
& +a_{2} \log ^{2} d b h+a_{3} \log h \\
& +a_{4} \log ^{2} h
\end{aligned}
$$

where $h$ is the tree height $(m), d b h$ is the diameter at breast height $(\mathrm{cm})$ and $a_{0}, \ldots$, $a_{4}$ are the regression coefficients (spruce: $a_{0}=-4.18161, a_{1}=2.08131, a_{2}=-0.11819, a_{3}=$ $0.70119, a_{4}=0.148181$; beech: $a_{0}=-4.11122, a_{1}$ $=1.30216, a_{2}=0.23636, a_{3}=1.26562, a_{4}=$ 0.079661; fir: $a_{0}=-4.46414, a_{1}=2.19479, a_{2}=-$ $\left.0.12498, a_{3}=1.04645, a_{4}=-0.016848\right)$ established for the most important species in Romania's forests (Giurgiu et al. 2004).

To analyse structural diversity, the Gini index (Gini 1912) was calculated for each development phase (Klopcic \& Boncina 2011). Each tree was assigned to one of four virgin forest's development phases (Feldmann et al. 2018): (i) optimum; (ii) ageing; (iii) breakdown and dieback; (iv) rejuvenantion. The classical method (Mayer 1976) was applied for delimitating the development phases on the ground, using the following stand characteristics: number of trees, basal area, volume growth, stand class, vitality, mortality, age structure, stability of the stand and regeneration (see also Tab. S1 in Supplementary material). GPS technology was used for spatial delimitation of the development phases.

All statistical analyses were conducted using the R software (R Core Team 2014).

\section{Results}

All development phases (optimum, ageing, breakdown and dieback, rejuvenation) 
Tab. 1 - Main structural characteristics of the four development phases recorded at the studied virgin forest.

\begin{tabular}{|c|c|c|c|c|c|}
\hline \multirow[b]{2}{*}{ Characteristics } & \multicolumn{4}{|c|}{ Development phase } & \multirow[b]{2}{*}{ Total } \\
\hline & Optimum & Ageing & $\begin{array}{c}\text { Breakdown } \\
\text { and dieback }\end{array}$ & Rejuvenation & \\
\hline Number of trees & 17 & 112 & 178 & 90 & 397 \\
\hline Covered area (\%) & 31 & 21 & 41 & 7 & 100 \\
\hline Basal area $\left(\mathrm{m}^{2}\right)$ & 1.08 & 7.01 & 20.06 & 15.58 & 43.73 \\
\hline Gini Index & 0.57 & 0.78 & 0.69 & 0.52 & - \\
\hline Min radial growth (ir, mm) & 0.42 & 0.15 & 0.14 & 0.15 & 0.14 \\
\hline Max radial growth (ir, mm) & 2.04 & 3.56 & 4.36 & 4.33 & 4.36 \\
\hline Mean radial growth (ir, mm) & 0.97 & 1.06 & 1.08 & 1.42 & 1.15 \\
\hline Min age (yrs) & 32 & 11 & 24 & 27 & 11 \\
\hline Max age (yrs) & 329 & 365 & 328 & 334 & 365 \\
\hline Average age (yrs) & 115.88 & 89.17 & 112.46 & 145.72 & 113.57 \\
\hline Mean unitary volume $\left(\mathrm{m}^{3}\right)$ & 0.70 & 0.86 & 1.74 & 2.83 & 1.69 \\
\hline
\end{tabular}

were found in the study plot, but with a high variability in the size of the area covered by each phase (Tab. 1). The small area covered by early development phases is the consequence of the lower limit $(8 \mathrm{~cm})$ adopted for trees to be inventoried. The number of trees in each development phase was highly positively correlated with the basal area $(r=0.896 ; p<0.01562)$. The smallest number of trees was recorded for the optimum phase, followed by the rejuvenation phase, with 90 trees. The breakdown and dieback and ageing phases were well represented within the plot, with 178 and 112 trees, respectively. The optimum phase covered 14 per cent of the total surface area of the plot, with basal areas of $1.05 \mathrm{~m}^{2}$. With the exception of the optimum phase, mean radial growth showed a weak correlation with the average age of trees $(r=0.25, p<0.001)$, as well as with tree volume $(r=0.35, p<0.001)$. The volume per tree (overall aboveground tree volume for broadleaves and trunk volume for coniferous) ranged between $0.11 \mathrm{~m}^{3}$ and $3.28 \mathrm{~m}^{3}$.

\section{Characterisation of the stand using $d b h$} theoretical distributions

Theoretical functions (normal, gamma, weibull, exponential) were fitted to the experimental distribution of diameters (Fig. 2). All the statistical tests applied (Kolmogorov-Smirnov, Anderson-Darling and chisquare - Tab. 2) confirmed that none of these distributions corresponds to that observed in the virgin forest stand at Penteleu-Viforâta. Therefore, a mixture of three normal distributions was used to describe the stand structure (Fig. 3). The significant $(p<0.001)$ fitting confirmed the existence of a three-modal distribution of tree diameters, where each peak corresponds to a storey position in the canopy (see also Tab. S2 in Supplementary material).

Similar results were obtained when theoretical functions were fitted on observed diameter distribution of each development phase (whenever sufficient samples were available), except for the rejuvenation

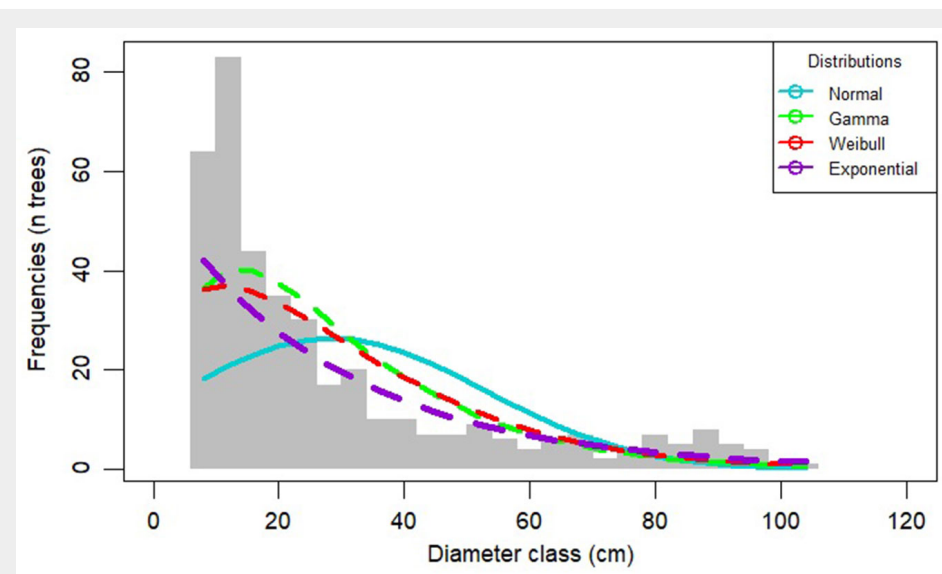

Fig. 2 - Theoretical (colored lines) vs. experimental (bars) distributions of tree dbh at the PenteleuViforâta virgin forest.

Tab. 2 - Goodness-of-fit of theoretical functions to the experimental distribution of diameters at the Penteleu-Viforâta virgin forest.

\begin{tabular}{lcccc}
\hline \multirow{2}{*}{$\begin{array}{l}\text { Theoretical } \\
\text { Function }\end{array}$} & CHI & $\begin{array}{c}\text { Kolmogorov-Smirnov } \\
\text { NO/YES }\end{array}$ & $\begin{array}{c}\text { Kolmogorov- } \\
\text { Smironov }\end{array}$ & $\begin{array}{c}\text { Anderson- } \\
\text { Darling }\end{array}$ \\
\hline Normal & 595.53 & rejected & 0.20 & 31.07 \\
Weibull & 212.92 & rejected & 0.15 & 14.09 \\
\hline Gamma & 193.78 & rejected & 0.12 & 13.78 \\
\hline Exponential & 217.63 & rejected & 0.24 & 19.78 \\
\hline
\end{tabular}

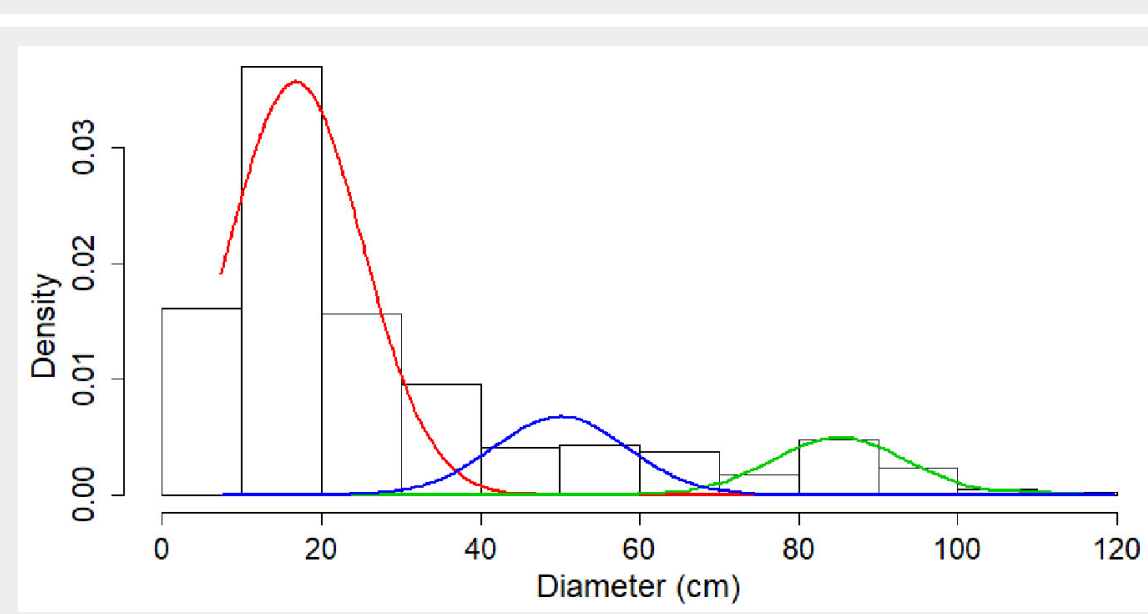

Fig. 3 - The mixture of three normal distributions used to describe the distribution of diameters at the Penteleu-Viforâta virgin forest. The significant $(p<0.001)$ fitting confirmed the existence of a three-modal distribution, where each peak corresponds to a storey position in the canopy. 
Tab. 3 - Goodness-of-fit of theoretical functions to the experimental distribution of diameters for each development phase at the Penteleu-Viforâta virgin forest. Results for the optimum phase are not reported due to the limited sample size.

\begin{tabular}{llrrr}
\hline $\begin{array}{l}\text { Theoretical } \\
\text { function }\end{array}$ & $\begin{array}{l}\text { Statistical } \\
\text { test }\end{array}$ & Ageing & Rejuvenation & $\begin{array}{r}\text { Breakdown } \\
\text { and dieback }\end{array}$ \\
\cline { 2 - 5 } Normal & KS & 0.24 & 0.12 & 0.21 \\
& AD & 13.67 & 1.37 & 14.32 \\
& CHI & 215.94 & 27.79 & 198.81 \\
\cline { 2 - 5 } Weibull & TEST & Reject & Fitted & Reject \\
& KS & 0.21 & 0.07 & 0.15 \\
& AD & 7.47 & 0.40 & 6.87 \\
& CHI & 94.99 & 15.57 & 74.25 \\
\hline \multirow{5}{*}{ Gamma } & TEST & Reject & Fitted & Reject \\
& KS & 0.16 & 0.06 & 0.16 \\
& AD & 6.75 & 0.37 & 6.73 \\
& CHI & 75.68 & 14.21 & 65.28 \\
& TEST & Reject & Fitted & Reject \\
\hline Exponential & KS & 0.31 & 0.19 & 0.23 \\
& AD & 10.17 & 3.63 & 9.60 \\
& CHI & 115.37 & 24.52 & 80.02 \\
& TEST & Reject & Reject & Reject \\
\hline
\end{tabular}

phase (Tab. 3) where significant ( $p<0.001)$ Relation between development phase fitting was found for normal, gamma and and species

weibull functions. In the case of all other Beech was the dominant species in all layphases and functions, fitting was rejected. ers and phases, being present in large num-

Tab. 4 - Species distribution in relation with development phase.

\begin{tabular}{lcccc}
\hline \multirow{2}{*}{ Development phase } & \multicolumn{5}{c}{ Number of trees } \\
\cline { 2 - 5 } & Fir & Beech & Spruce & Total \\
\hline Ageing & 21 & 82 & 9 & 112 \\
Breakdown and dieback & 52 & 108 & 18 & 178 \\
\hline Optimum & 5 & 11 & 1 & 17 \\
\hline Rejuvenation & 18 & 58 & 14 & 90 \\
\hline Total & 96 & 259 & 42 & 397 \\
\hline
\end{tabular}

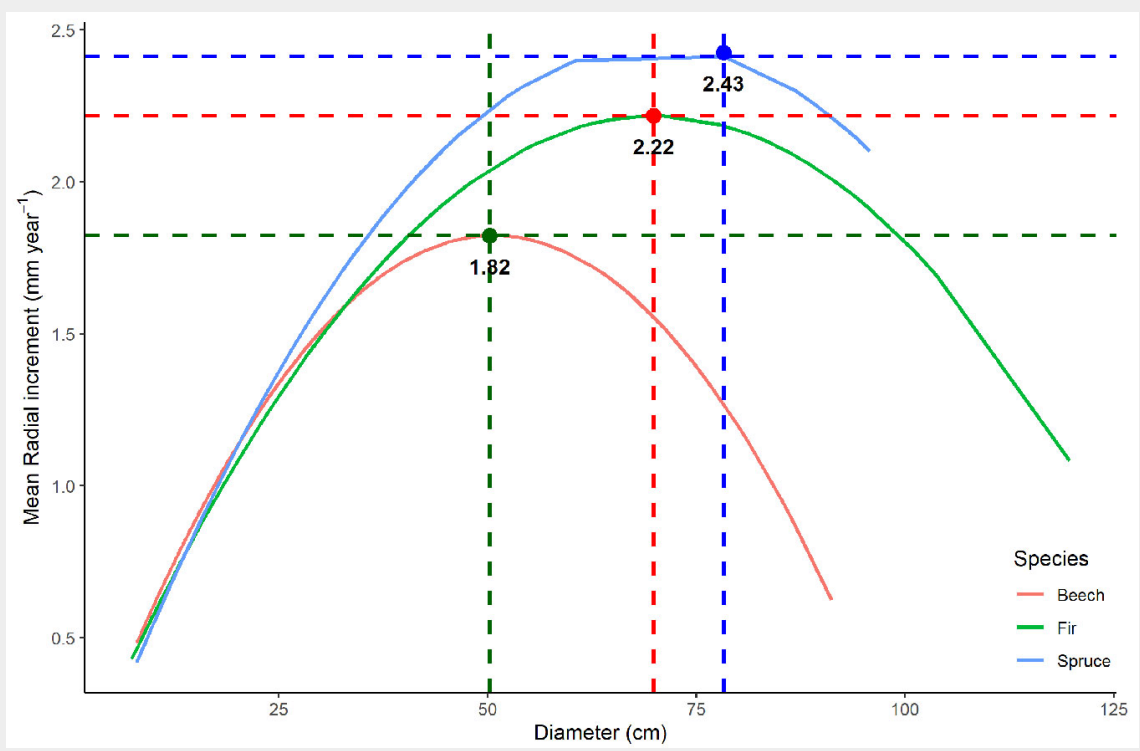

Fig. 4 - Species-specific growth models based on wood core samples analysis. bers in every development phase. Ageing, breakdown dieback and rejuvenation were the three phases which mainly cover the study plot, and they were well covered by all three species (beech, fir and spruce). As mentioned above, the limited number of trees falling in the optimum development phase is the consequence of the adoption of a lower limit $(8 \mathrm{~cm})$ for trees to be inventoried (Tab. 4 ).

\section{Relation between age and species}

The predominance of trees belonging to lower age class (80-100 years old) was observed in the studied plot. However, a significant number of trees belonging to upper age class were also found, but with a lower frequency. Beech reach an age of 380 years in the Penteleu-Viforâta virgin forest, while fir and spruce are no longer present after 340 years (Tab. S3 in Supplementary material). Most of beech trees, however, are in the lower age classes, with the highest abundance recorded in the age class $80-120$ years. Both beech and fir have an uneven-aged distribution characterised by a large number of trees in the younger classes, whereas for spruce, the distribution is platykurtic, with a similar number of trees in every age class.

\section{Relation between diameter and growth} by species

The analysis of mean radial growth based on wood core samples allowed to build species-specific growth models (Fig. 4), which revealed high increment values for all the species. For beech, the highest radial increment $(1.82 \mathrm{~mm}$ year-1) was recorded for trees with a diameter of $50 \mathrm{~cm}$, while for fir and spruce higher increment values were observed at larger diameters $\left(2.22 \mathrm{~mm}\right.$ year ${ }^{-1}$ at $70 \mathrm{~cm}$ diameter and 2.43 $\mathrm{mm}$ year ${ }^{-1}$ at $75 \mathrm{~cm}$ diameter, respectively Fig. 4). However, after reaching these maximum increment levels, radial growth rate decreases and trees enter a senescent overstory stage. This is characterised by high mortality with the stand density curve sloping downward, reaching the diameter limit. In our study, the diameter limit corresponds to the category of $84 \mathrm{~cm}$ (Fig. 5).

\section{Discussion}

Compared with even-aged stands, virgin forests are thought to better withstand natural disasters, such as insect outbreaks, windthrows and severe drought, thanks to the co-occurrence of different development phases which ensure long-term sustainability and continuity of the forest ecosystem (Orman \& Dobrowolska 2017). The typical process of identification of development phases in virgin forests can suffer from subjectivity (Feldmann et al. 2018), whereas the adoption of quantitative methods to investigate stand dynamics based on repetitive measurements combined with GIS data and stand structural characteristics is required to obtain more precise and reliable results. 
In the studied forest, the number of trees per ha was 225-400 and the basal area was $32-47 \mathrm{~m}^{2}$. Such values are at the upper limit of the ranges reported in the literature for other old-growth European forests (Holeksa et al. 2009, Zenner et al. 2015). Also, the dominance of the ageing and breakdown and dieback phases at Penteleu-Viforâta is likely the result of the protection from wind provided by the surrounding reliefs. Indeed, the analysed plot is situated on a south-facing slope with dominant winds blowing from NNE, and this is similar to other virgin forests reported in the literature (Anić \& Mikac 2008).

The values of the Gini coefficient observed at Penteleu-Viforâta reflect the structural characteristics of each development phase and support the hypothesis of a high stability of the stand (Chivulescu et al. 2014). The lower values of Gini coefficient recorded in the rejuvenation phase indicate a reduced structural diversity. Contrastingly, high values were found in the ageing phase, thus indicating a higher structural diversity and stability. Moreover, the values of Gini coefficient recorded for each development phase were fairly similar to those reported in the literature for virgin forests (Zenner et al. 2015), i.e., 0.690.76 for the optimum phase, $0.51-0.64$ for the ageing phase and 0.51-0.60 for the rejuvenation phase. We believe that such values can be used as reference for further studies focused on virgin beech-fir-spruce forests in Europe. This information, along with the species growth models, could be relevant for the development of a model to manage cultivated forests based on evidences obtained from virgin forests (Pach \& Podlaski 2015), thereby increasing longterm functionality and stability of stands (Giurgiu 2013).

The diameter distribution of trees in our study area did not fit any of the most common distributions suited to managed forests, due to the structural complexity of each development phase in virgin forest ecosystems (Giurgiu 2013). It is known that diameters in uneven-aged forests do not follow a general theoretical distribution, although in some cases experimental data showed a fairly good fit to Weibull, Beta and Meyer distributions (Akhavan et al. 2012). In fact, the structure of a virgin forest stand keeps changing as a result of the balance of inputs and outputs. Inputs are provided by new areas covered by regeneration, and the outputs are the result of the high tree mortality rate due to the strong competition that exists in a virgin forest.

Regarding the relation between development phases and species, the dominance of beech in all development phases, especially in lower-diameter categories, confirms previous findings on this species (Diaci et al. 2008, Višnjić et al. 2015). In virgin beech-fir-spruce forests, disturbances are frequent, though balanced by rapid stand growth (Paluch et al. 2015). Since virgin ecosystems are not directly influenced by

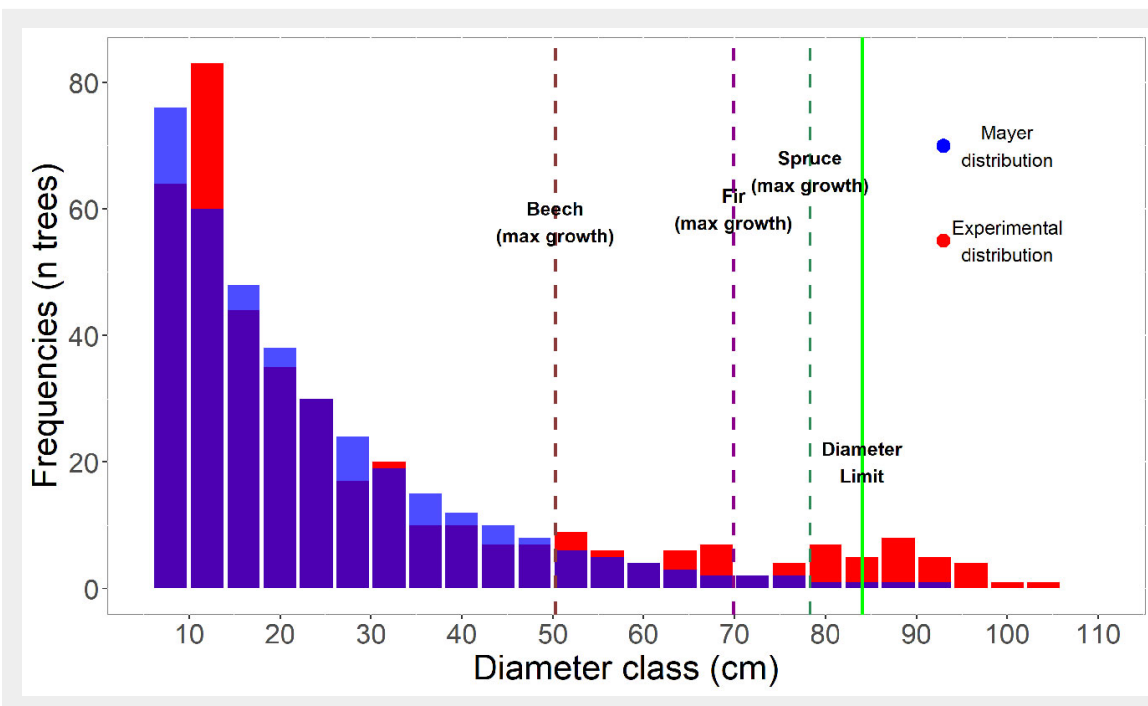

Fig. 5 - Stand diameter limit and maximum point of growth for beech, spruce and fir at Penteleu-Viforâta virgin forest.

any anthropic disturbances, this growth pattern may occur as a response to climate change (Višnjić et al. 2015). Furthermore, our results confirm the capacity of beech for regeneration and survival in the understory, showing an increase in growth even under the canopy (Wagner et al. 2010, Orman et al. 2018).

Leuschner \& Meier (2018) in a study on 42 European forest tree species, reported a maximum longevity of 450, 450 and 300 years for beech, fir and spruce, respectively. In this study, we found several individuals of beech reaching up to 380 years of age, confirming that the Penteleu-Viforâta forest is an optimum site for beech. Although the general climatic conditions suggest a good vegetation site also for the other two species (fir and spruce), their capacity to grow in the understory is lower than that of beech, and this affects their growth dynamics and longevity. Indeed, beech shows a superior capacity of surviving under stress conditions, making it more competitive than fir and spruce. This is reflected by the high-intensity growth of beech in the optimum phase, compared with the two conifers.

Uneven-aged stands are more productive than even-aged stands (Danescu et al. 2016); this also holds for mixed forests compared to pure stands (Pretzsch et al. 2013). The most common natural mixed composition in uneven-aged forests of Central Europe consists of beech, spruce and fir, due to their ecological complementarity. Nonetheless, these species show different growth dynamics and competitive ability, particularly in an uneven-aged forest. As mentioned above, beech has a higher capacity to survive in the understory (Bose et al. 2017) due to a well-developed root system reaching deeper soil layers. Moreover, beech growth has a low variability compared to the conifer species (Vrška et al. 2009), as a consequence of its capacity to endure a wider range of environmen- tal conditions (including drought). In general, beech shows high growth rates up to approximately 100-120 years of age, while spruce and fir outstrip beech productivity and maintain growth longer than beech and at a higher level, as indicated from the different peaks of mean radial growth for each species observed in this study.

The identification of the maximum growth increment by wood core analysis and the ascertainment of the diameter limit for each species could help define silvicultural practices aimed at optimizing selective cutting in uneven-aged and/or mixed stands. For virgin forests, the diameter limit is taken, from the physiological point of view, as the last category of the diameter distribution a living tree can reach (Seceleanu 2012). In uneven-aged forest management, the maximum point of species growth can be used for predicting the diameter limit of the stand. The diameter limit is dynamic, depending on the site species and the stand history. According to Meyer's negative exponential distribution, the diameter limit is the diameter category with a frequency of one tree.

\section{Conclusions}

Virgin forests are a natural heritage of great value, offering solutions and structural models for sustainable forest management. The analysis of development phases of virgin forests may provide important information to be included in silvicultural practices aimed at enhance the stability and functionality of these ecosystems.

The structural diversity of the Penteleu-Viforâta virgin forest was analyzed by the Gini index. We observed the dominance of the breakdown and dieback as well as ageing development phases, while maximum and minimum stability were recorded for ageing and rejuvenation phases.

Tree diameter distribution did not match any of the tested theoretical functions, due to the complexity of the stand structure 
and its dynamics continuously changing in time and space. The study of the relation between development phases and species confirmed the dominance of beech in all phases as a consequence of its competitive ability and capacity to endure a wider range of stressful conditions. Moreover, the wood core analysis revealed a different mean radial increment and maximum radial growth for the three species analyzed, which should be taken into account by forest management planners when establishing the diameter limit.

Virgin forests can be considered as in situ laboratories for forest research, particularly for better understanding the principles underlying the stability and functionality of these ecosystems. These types of forests provide a vast array of resources, offering at the same time a higher level of protection, conservation and biodiversity. In this context, further research on development phases in virgin forests are needed in order to devise sustainable forest management strategies.

\section{References}

Akhavan R, Sagheb-Talebi K, Zenner EK, Safavimanesh F (2012). Spatial patterns in different forest development stages of an intact oldgrowth Oriental beech forest in the Caspian region of Iran. European Journal of Forest Research 131: 1355-1366. - doi: 10.1007/s10342-0120603-z

Anderson TW, Darling DA (1954). A test of goodness of fit. Journal of the American Statistical Association (268): 765-769. - doi: 10.2307/22815 37

Anić I, Mikac S (2008). Struktura, tekstura i pomladivanje dinarske bukovo jelove paršume Corkova Uvala [Structure, texture and regeneration of Dinaric beech-fir virgin forest of Corkova Uvala]. Šumarski list 11 (12): 505-515. [in Croatian]

Baty F, Ritz C, Charles S, Brutsche M, Flandrois JP, Delignette-Muller ML (2015). A toolbox for nonlinear regression in $\mathrm{R}$ : the package nlstools. Journal of Statistical Software 66 (5): 1-21. - doi: 10.18637/jss.v066.io5

Bose A, Weiskittel A, Wagner R (2017). Occurrence, pattern of change, and factors associated with American beech-dominance in stands of the northeastern USA forest. Forest Ecology and Management 392: 202-212. - doi: 10.1016/j. foreco.2017.03.003

Brzeziecki B, Bielak K, Bolibok L, Drozdowski S, Zajaczkowski J, Zybura H (2018). Structural and compositional dynamics of strictly protected woodland communities with silvicultural implications, using Bialowieza Forest as an example. Annals of Forest Science. 75: 89. - doi: 10.1007/ s13595-018-0767-x

Chivulescu S, Badea O, Tomescu R, Silaghi D, Leca S, Turcu DO (2014). Structural features of virgin beech forests in Semenic Mountains. The dynamic structure of virgin beech forest P2O Semenic between 2005-2013. Proceedings of Romanian Academy-Series B: Chemistry, Life Science and Geoscience 16 (2): 115-124.

Danescu A, Albrecht AT, Bauhus J (2016). Structural diversity promotes productivity of mixed, uneven-aged forests in southwestern Germany. Oecologia 182: 319-333. - doi: 10.1007/s00442-01 6-3623-4

Delignette-muller ML, Dutang C (2015). fitdistrplus: an $\mathrm{R}$ package for fitting distributions. Journal of Statistical Software 64 (4): 1-34. doi: 10.18637 /jss.v064.io4

Diaci J, Rozenbergar D, Mikac S, Anic I, Hartman $\mathrm{T}$, Boncina A (2008). Long-term changes in tree species composition in old-growth Dinaric beech-fir forest. Glasnik za Sumske Pokuse 42: 13-28.

Feldmann E, Glatthorn J, Hauck M, Leuschner C (2018). A novel empirical approach for determining the extension of forest development stages in temperate old-growth forests. European Journal of Forest Research 137: 321-335. doi: 10.1007/s10342-018-1105-4

Gini C (1912). Variabilità e mutabilità [Variability and mutability]. Cuppini, Bologna, Reprinted in "Memorie di metodologica statistica" (Pizetti E, Salvemini T eds). Libreria Eredi Virgilio Veschi, Rome, Italy, pp. 156. [in Italian]

Giurgiu V, Decei I, Draghiciu D (2004). Metode si tabele dendrometrice [Forest mensuration methods and tables]. Editura Ceres, Bucharest, Romania, pp. 575. [in Romanian]

Giurgiu V (2013). Padurile virgine si cvasivirgine ale Romniei [Virgin and quasi-virgin Romanian forests]. Ed. Academiei Romne, Bucharest, Romania, pp. 390. [in Romanian]

Hassani M, Amani M (2010). Investigation on structure of oriental beech (Fagus orientalis Lipsky) stand at optimal stage in Sangdeh forest. Iranian Journal of Forest and Poplar Research 18 (2): 163-176. [online] URL: http://www.cabdir ect.org/cabdirect/abstract/20113021091

Hogg RV, Craig AT (1978). Introduction to mathematical statistics ( $4^{\text {th }}$ edn). Macmillan, New York, USA, pp. 438.

Holeksa J, Saniga M, Szwagrzyk J, Czerniak M, Staszynska K, Kapusta P (2009). A giant tree stand in the West Carpathians: an exception or a relic of formerly widespread mountain European forests? Forest Ecology and Management 257 (7): 1577-1585. - doi: 10.1016/j.foreco.2009.0 1.008

Holmes RL (1983). Computer-assisted quality control in tree-ring dating and measurement. Tree-Ring Bulletin 43: 69-78. [online] URL: http://repository.arizona.edu/handle/10150/2612 23

Klopcic M, Boncina A (2011). Stand dynamics of silver fir (Abies alba Mill.) - European beech (Fagus sylvatica L.) forests during the past century: a decline of silver fir? Forestry 84 (3): 259-271. doi: 10.1093/forestry/cpro11

Korpel S (1978). Obnova lesnych porastov v rubáòovom sposobe hospodárenia [Restoration of forest stands in the ruby way of management]. Pesteni lesù, SZN, Prague, Czech Republic, pp. 216-359 [in Slovakian]

Kral F (1979). Spät- und postglaziale Waldgeschichte der Alpen auf Grund der bisherigen Pollenanalysen [Late and postglacial forest history of the Alps based on the previous pollen analyzes]. Veröffentlichungen des Institutes für Waldbau an der Universität für Bodenkultur, Agrarverlag, Vienna, Austria, pp. 175. [in German]

Král K, Danek P, Janík D, Kruček $M$, Vrška T
(2018). How cyclical and predictable are Central European temperate forest dynamics in terms of development phases? Journal of Vegetation Science 29 (1): 84-97. - doi: 10.1111/jvs.12590

Leibundgut H (1982). Europäische Urwälder der Bergstufe: dargestellt für Forstleute, Naturwissenschafter und Freunde des Waldes [European primeval forests of the Bergstufe: represented for foresters, naturalists and friends of the forest]. Haupt, Bern-Stuttgart, pp. 308. [in German]

Leuschner C, Meier IC (2018). The ecology of Central European tree species: trait spectra, functional trade-offs, and ecological classification of adult trees. Perspectives in Plant Ecology, Evolution and Systematics 33: 89-103. - doi: 10.1016/j.ppees.2018.05.003

Marshall AW, Olkin I (1967). A multivariate exponential distribution. Journal of the American Statistical Association 62 (317): 30-44. - doi: 10.1080/01621459.1967.10482885

Mayer H (1976). Gebirgswaldbau - Schutzwaldpflege [Mountain forestry, protective forest care]. Gustav Fisher Verlang, Stuttgart, Germany, pp. 435. [in German]

Meyer HA (1952). Structure, growth, and drain in balanced uneven-aged forests. Journal of Forestry 50 (2): 85-92. - doi: 10.1093/jof/50.2.85 Nawaz S, Nazrul IM (1980). The Weibull distribution as a general model for forecasting technological change. Technological Forecasting and Social Change 18 (3): 247-56. - doi: 10.1016/00401625(80)90026-8

Orman O, Dobrowolska D (2017). Gap dynamics in the Western Carpathian mixed beech oldgrowth forests affected by spruce bark beetle outbreak. European Journal of Forest Research 136: 571-581. - doi: 10.1007/s10342-017-1054-3

Orman O, Dobrowolska D, Szwagrzyk J (2018). Gap regeneration patterns in Carpathian oldgrowth mixed beech forests - Interactive ef fects of spruce bark beetle canopy disturbance and deer herbivory. Forest Ecology and Management 430: 451-459. - doi: 10.1016/j.foreco.20 18.08.031

O'Hara KL (2016). What is close-to-nature silviculture in a changing world? Forestry 89 (1): 1-6. doi: 10.1093/forestry/cpv043

Pach M, Podlaski R (2015). Tree diameter structural diversity in Central European forests with Abies alba and Fagus sylvatica: managed versus unmanaged forest stands. Ecological Research 30 (2): 367-384. - doi: 10.1007/s11284-014-1232-4 Paluch JG, Kolodziej Z, Pach M, Jastrzebski R (2015). Spatial variability of close-to-primeval Fagus-Abies-Picea forests in the Western Carpathians (Central Europe): a step towards a generalised pattern. European Journal of Forest Research 134: 235-246. - doi: 10.1007/s10342014-0846-y

Parviainen J (2005). Virgin and natural forests in the temperate zone of Europe. Forest Snow and Landscape Research 18: 9-18.

Patel JK, Read CB (1996). Handbook of the normal distribution ( $2^{\text {nd }}$ edn). Statistics Textbooks and Monographs, CRC Press, New York, USA, pp. 1-427. [online] URL: http://books.google. com/books?id=zoVLFoVFgUYC

Pretzsch H, Bielak K, Block J, Bruchwald A (2013). Productivity of mixed vs. pure stands of oak (Quercus petraea (Matt.) Liebl. and Quercus 
robur L.) and European beech (Fagus sylvatica L.) along an ecological gradient. European Journal of Forest Research 132 (2): 263-280. doi: $10.1007 / \mathrm{s} 10342-012-0673-y$

R Core Team (2014). R: a language and environment for statistical computing. R Foundation for Statistical Computing, Vienna, Austria. [online] URL: http://www.r-project.org/

Remmert H (1991). The mosaic-cycle concept of ecosystems. In: "The Mosaic-Cycle Concept of Ecosystems” (Billings WD, Golley F, Lange OL, Olson JS, Remmert H eds). Ecological Studies, vol. 85, Springer, Berlin, Heidelberg, Germany, pp. 168.

Schuck A, Parviainen J, Bücking W (1994). A review of approaches to forestry research on structure, succession and biodiversity of undisturbed and semi-natural forests and woodlands in Europe. European Forest Institute, Joensuu, Finland, pp. 42.

Seceleanu I (2012). Amenajarea Padurilor - Organizare si conducere structurala [Forest management - Organization and management]. Editura Ceres, Bucharest, Romania, pp. 505. [in Romanian]

Stephens MA (1979). Tests of fit for the logistic distribution based on the empirical distribution function. Biometrika 66 (3): 591-595. - doi: 10.1093/biomet/66.3.591

UN-ECE/FAO (2000). Forest resources of Europe, CIS, North America, Australia, Japan and New Zealand (industrialized temperate/boreal countries): UN-ECE/FAO contribution to the global forest resources Assessment 2000. UN EcOnomic Commission for Europe, FAO, Rome, Italy, pp. 445.

Vacek Z, Podrázsky V, Bílek L, Bulušek D, Stefančík I, Remeš J, Stícha V, Ambro R (2014). Structural diversity of autochthonous beech forests in Broumovske Steny National Nature Reserve, Czech Republic. Austrian Journal of Forest Science 131: 191-214.

Visnjić C, Balić B, Vojniković S, Mekić F, Uzunović A (2015). Structural characteristics, dynamics and texture development of virgin forest Ravna Vala on Bjelašnica. Faculty of Forestry, University of Sarajevo, vol. 2015, issue 2, BosniaHercegovina, pp. 100-112.

Vrška T, Adam D, Hort L, Kolár T, Janík D (2009). European beech (Fagus sylvatica L.) and silver fir (Abies alba Mill.) rotation in the Carpathians A developmental cycle or a linear trend induced by man? Forest Ecology and Management 258: 347-356. - doi: 10.1016/j.foreco.2009.
03.007

Wagner S, Collet C, Madsen P, Nakashizuka T, Nyland RD, Sagheb-Talebi K (2010). Beech regeneration research: from ecological to silvicultural aspects. Forest Ecology and Management 259: 2172-2182. - doi: 10.1016/j.foreco.2010.02.0 29

Zenner EK, Sagheb-talebi K, Akhavan R, Peck JE (2015). Integration of small-scale canopy dynamics smoothes live-tree structural complexity across development stages in old-growth Oriental beech (Fagus orientalis Lipsky) forests at the multi-gap scale. Forest Ecology and Management 335: 26-36. - doi: 10.1016/j.foreco.2014. 09.023

\section{Supplementary Material}

Tab. S1 - Virgin stands development phases.

Tab. S2 - Diameter distribution of trees on storey position.

Tab. S3 - Species distribution in relation with age.

Link: Chivulescu_3094@supplo01.pdf 